\title{
DOES GABAPENTIN RELIEVE ACUTE PREOPERATIVE ANXIETY?
}

\author{
Pathak $\mathrm{L}^{1}$
}

\section{ABSTRACT}

INTRODUCTION: The role of Gabapentin in relieving chronic pain, chronic anxiety disorders and acute postoperative pain is well known by now. Trials done with the administration of Gabapentin to treat preoperative anxiety showed mixed results. So, this study was conducted to test the hypothesis that premedication with Gabapentin 1200 mg versus placebo would reduce preoperative anxiety in patients undergoing open cholecystectomy under general anesthesia.

MATERIAL AND METHODS: A prospective, randomized, double blind and placebo controlled study was carried out at Universal College of Medical Sciences \& Teaching Hospital (UCMSTH) from August 2012 to Januray 2014. Total 160 adult patients of American Society of Anaesthesiologist (ASA) I and II were divided into 2 groups of 80 each. Patients in group 1 and group 2 received capsules Gabapentin $(1200 \mathrm{mg})$ or identical placebo capsules 2 hours prior to surgery respectively. Preoperative anxiety was assessed for three times using Anxiety Visual Analogue Scale (VAS) score. A uniform anesthetic technique was used in both groups. Parameters including preoperative and postoperative sedation scores and various side effects were also observed.

RESULTS: VAS anxiety scores after one hour of drug intake (47.19 \pm 17.37 versus $63.13 \pm 17.77)$ and just before induction of anaesthesia (43.81 \pm 17.72 versus $81.81 \pm 21.57)$ were significantly lower in Gabapentin group as compared to placebo group. No patient experienced any significant side effects or sedation in either group throughout the study period.

CONCLUSIONS: Premedication with $1200 \mathrm{mg}$ Gabapentin in open cholecystectomy patients significantly reduced preoperative anxiety as evident by decrease in anxiety VAS scores without any significant side effects.

KEY WORDS: Acute anxiety, Gabapentin, Preemptive analgesia, Premedication

1. Associate Professor, Department of Anesthesiology, Universal College of Medical Sciences \& Teaching Hospital, Bhairahawa, Nepal

\author{
For Correspondence \\ Dr. Laxmi Pathak \\ Associate Professor, \\ Department of Anesthesiology, \\ Universal College of Medical Sciences \& Teaching Hospital, \\ Bhairahawa, Nepal \\ E-mail: laxmi_pathak22@yahoo.com
}




\section{INTRODUCTION}

Does Gabapentin premedication relieve acute preoperative anxiety? Though it has been effectively used for chronic pain and anxiety disorders, its role in relieving acute anxiety has to be established.

Preoperative anxiety may be increased through ignorance of anesthetic and surgical procedures, given past experience and patient's psychological profile. ${ }^{1}$ It also causes adverse physical response preoperatively by exerting significant haemodynamic stress response resulting in increased cardiac output and myocardial oxygen consumption. It adversely influences induction of anesthesia, postoperative anxiety and pain, length of hospital stay and patient recovery. It also makes pain control more difficult. ${ }^{2}$ Prevention of anxiety is therefore a major issue during the perioperative care.

Literature search didn't reveal much information about its effectiveness in relieving acute preoperative anxiety. Thus, this study was carried out to evaluate the effect and safety of Gabapentin premedication on preoperative anxiety in patients undergoing elective open cholecystectomy.

\section{MATERIAL AND METHODS}

This was an open prospective, randomized, placebo controlled, double blind study. Study was conducted in UCMS TH, Bhairahawa, Nepal, over a period of 18 months. After taking approval of institutional ethics committee and written informed consent from patients, study was carried out in 160 adult patients (18-60 yrs) of ASA Grade I and II of both genders undergoing elective open cholecystectomy under general anaesthesia.

Exclusion criteria's were patients having body weight more than $20 \%$ of ideal body weight, history of chronic pain conditions, drug or alcohol abuse, Gabapentin hypersensitivity, administration of sedatives within 24 hours of scheduled surgery, systemic diseases like uncontrolled hypertension and diabetes mellitus, bronchial asthma, valvular heart diseases and coronary artery disease, renal and hepatic diseases, and neuromuscular or psychiatric disorder.

At the time of preanesthetic evaluation, patients were explained about $100 \mathrm{~mm}$ VAS for anxiety that is Anxiety VAS $(0=$ no anxiety to $100=$ worst imaginable anxiety $)$ and were kept nil per oral after midnight before surgery.

On the day of surgery, patients were divided into 2 groups of 80 each and assigned randomly in a double blind fashion via random number table to receive either capsule Gabapentin
$1200 \mathrm{mg}$ (Group 1 or Gabapentin group) or an identical looking placebo (Group 2 or control group) orally 2 hours prior to surgery ( $\mathrm{n}=40$ per group). The study medication was prepared by the hospital pharmacy in identical appearing capsules and was put in 160 numbered envelopes containing 2 capsules each to maintain blinding. The capsules were kept in pharmacy and were taken only when required. No sedative premedication other than Gabapentin was used. The patients, attending anesthesiologists, persons involved in data collection and nurses involved in patient's care in the recovery room were all blinded to the content of the study medication.

In the operation room, routine monitoring including electrocardiography (ECG), non invasive blood pressure (NIBP) and pulse oximeter $\left(\mathrm{SpO}_{2}\right)$ was applied and preoperative baseline vitals were recorded. The level of anxiety was assessed first at the time of drug intake (Anxiety VAS-1), then one hour after the drug intake in pre-anesthesia preparation room (Anxiety VAS-2) and lastly, just before induction inside the operating room (Anxiety VAS-3). Preoperative sedation scores were also recorded for three times along with VAS. Uniform anaesthetic technique was used in all groups. Anesthesia was induced with intravenous (i.v) Propofol $2 \mathrm{mg} / \mathrm{kg}$ followed by Vecuronium $0.1 \mathrm{mg} / \mathrm{kg}$ to facilitate orotracheal intubation. Intravenous Morphine $0.1 \mathrm{mg} / \mathrm{kg}$ bolus was given for intraoperative analgesia. Anaesthesia was maintained with Oxygen, Isoflurane 2 volume $\%$ and intermittent $1 \mathrm{mg}$ bolus of Vecuronium. All patients received intramuscular Diclofenac $75 \mathrm{mg}$ and intravenous Ondansetron 4mg after removal of gall bladder. Isoflurane was discontinued at the beginning of skin closure. At the end of surgery and after initiation of spontaneous respiration, reversal of neuromusmular blockade was done with intravenous Neostigmine $0.05 \mathrm{mg} / \mathrm{kg}$ and Glycopyrrolate $0.01 \mathrm{mg} / \mathrm{kg}$. After patient started obeying commands, trachea was extubated. Throughout intraoperative periods vitals monitoring of all patients were done and were within normal ranges. Then, patients were shifted to post anesthesia care unit (PACU) for observation for 12 hours. Intravenous Paracetamol 1 gram was given slowly as a drip over an hour for postoperative pain in PACU. Side effects like nausea, vomiting, retching, dizziness, vertigo, sedation, visual disturbance, headache and respiratory depression (Respiratory rate $<8 / \mathrm{min}$ and Oxygen saturation, $\mathrm{SpO} 2<90 \%$ without oxygen supplement) were also observed and recorded for 12 postoperative hours and were treated whenever indicated like respiratory depression or $\mathrm{SpO}_{2}<90 \%$ was treated with oxygen supplementation, $\geq 2$ episodes of vomiting was treated with Ondansetron $4 \mathrm{mg}$ intravenously.

Both pre and postoperative sedation was measured on a 4point categorical scale derived from the Ramsay Score as 
follows:

$0=$ alert, aware

$1=$ somnolent, arousable by verbal contact.

$2=$ somnolent, arousable by tactile stimulation.

$3=$ asleep, arousable by painful stimulation

Statistical Analysis-.Morphometric and demographic characteristics of patients, clinical variables and preoperative anxiety in both Gabapentin and control groups were compared with student's t-test. Results are expressed as mean \pm SD. P $<$ 0.05 was considered statistically significant.

\section{RESULTS}

The two groups were comparable with respect to demographic characteristics, preoperative vitals and length of anesthesia. (Table 1)

\section{Table1:Patient characteristics and preoperative data}

\begin{tabular}{|l|c|c|c|}
\hline Parameters & Group 1 (n=80) & Group2 (n=80) & P value \\
Age(years) & $39.28 \pm 12.24$ & $40.44 \pm 12.55$ & 0.554 \\
\hline Wt (kg) & $53.89 \pm 7.85$ & $54.43 \pm 8.29$ & 0.674 \\
\hline $\begin{array}{l}\text { L-Anesthesia } \\
\text { (min) }\end{array}$ & $58.23 \pm 6.98$ & $58.21 \pm 7.78$ & 0.991 \\
\hline $\begin{array}{l}\text { Heart Rate } \\
\text { (beats/min) }\end{array}$ & $81.41 \pm 13.36$ & $82.33 \pm 13.30$ & 0.666 \\
\hline $\begin{array}{l}\text { Systolic BP } \\
\text { (mmHg) }\end{array}$ & $124.21 \pm 10.33$ & $126.24 \pm 10.72$ & 0.226 \\
\hline $\begin{array}{l}\text { Diastolic BP } \\
\text { (mmHg) }\end{array}$ & $77.20 \pm 7.21$ & $75.97 \pm 6.76$ & 0.270 \\
\hline $\begin{array}{l}\text { RR (breaths/min) } \\
\text { (bPO }\end{array}$ & $12.38 \pm 1.42$ & $12.60 \pm 1.49$ & 0.332 \\
\hline $\mathrm{SPO}_{2}(\%)$ & $99.68 \pm 0.49$ & $99.59 \pm 0.56$ & 0.301 \\
\hline
\end{tabular}

All the values are in mean $( \pm)$ SD.

Preoperative VAS anxiety scores at the time of drug administration were similar in both the groups but VAS anxiety scores after one hour of drug intake and just before induction were significantly lower in Gabapentin group than in control group. ( Table 2)

Table 2: Preoperative anxiety VAS scores

\begin{tabular}{|l|c|c|c|}
\hline & Group 1(n=80) & Group 2 (n=80) & P value \\
\hline Anxiety VAS 1 & $77.31 \pm 19.02$ & $70.00 \pm 21.88$ & 0.25 \\
\hline Anxiety VAS 2 & $47.19 \pm 17.37$ & $63.13 \pm 17.77$ & 0.000 \\
\hline Anxiety VAS 3 & $43.81 \pm 17.72$ & $81.81 \pm 21.57$ & 0.000 \\
\hline
\end{tabular}

All the values are in mean $( \pm) \mathrm{SD}$.

Preoperatively, all patients had sedation score of zero in either group. Postoperative sedation scores were also observed. It was recorded at the time of admission in PACU, then every 15 minutes for the first 1 hour and hourly for remaining 11 hours. Maximum sedation score observed throughout the study period was 1.

Table 3: Postoperative sedation scores

\begin{tabular}{|l|l|l|l|l|l|}
\hline $\begin{array}{l}\text { Sedation } \\
\text { Scores }\end{array}$ & Groups & $\begin{array}{l}\text { PACU } \\
\text { admission }\end{array}$ & $\begin{array}{l}\mathbf{1 5} \\
\text { minutes }\end{array}$ & $\begin{array}{l}\mathbf{3 0} \\
\text { minutes }\end{array}$ & $\begin{array}{l}\mathbf{4 5} \\
\text { minutes }\end{array}$ \\
\hline 0 & Group 1 & 6 & 71 & 78 & 80 \\
\cline { 2 - 6 } & Group 2 & 9 & 72 & 77 & 80 \\
\hline \multirow{2}{*}{1} & Group 1 & 74 & 9 & 2 & - \\
\cline { 2 - 6 } & Group 2 & 71 & 8 & 3 & - \\
\hline
\end{tabular}

As shown in Table 3, at the time of admission in PACU, only 15 patients were awake and alert having the sedation score of zero whereas 145 patients had sedation score of 1 . But, at 45 minutes of admission in PACU, all the patients of either group had sedation score of Zero. Thereafter, they all were awake and alert throughout the study period.

Various side effects mentioned above were observed and recorded for 12 postoperative hours. Only one episode of nausea was present in 3 patients of Group 1 and in 2 patients of Group 2. Except nausea, no other side effects were seen in any patient in either group.

\section{DISCUSSION}

Gabapentin is an inhibitory neurotransmitter. The mechanisms of action is mediated via GABA B receptor, enhancement of $\mathrm{N}$ methyl D-aspartate current at GABAergic interneurons, blockade of AMPA (a-amino-3-hydroxy-5-methyl-4isoxazolepropionic acid) receptors in the spinal cord and activation of ATP (adenosine triphosphate) sensitive potassium channels leading to hyperpolarization. Also, its binding in a state dependent manner to the alpha- 2 delta subunit of voltage gated $\mathrm{Ca}$ channels in overexcited presynaptic neurons reduce release of excitatory neurotransmitters and thereby reducing levels of anxiety and pain.

Gabapentin has known antinociceptive, antihyperalgesic and anxiolytic properties. Studies have found that pre-emptive use of gabapentin before surgery is better than postoperative administration due to its antihyperalgesic properties. ${ }^{4-6}$

Pretreatment with a single dose gabapentin blocked the development of hyperalgesia and tactile allodynia for upto 2 days in a rat model of postoperative pain, while gabapentin 1 
hour after intervention reduced symptoms for only three hours. ${ }^{7}$ Gabapentin crosses blood brain barrier rapidly and its concentration in brain tissue is nearly as high as in blood when administered approximately 2 hours before surgical stimuli. ${ }^{8}$ So in this study, Gabapentin was used preemptively 2 hours prior to induction.

Few studies have been done till date regarding its use for acute anxiety relief and is still a controversial issue. Common drug used to reduce preoperative anxiety is Benzodiazepines. But unlike Benzodiazepines, Gabapentin has anxiolytic effect at low dose with lack of amnesic effect, cognition deficits and drug interaction. It does not need plasma monitoring and has less dependence or abuse liability.

Reduced anxiety level without any adverse effect of gabapentin on memory was initially found in rat models. ${ }^{10}$ Similar finding was found in another study suggesting its potential advantage over the existing anxiolytics that causes amnesia at doses used for the treatment of anxiety disorders. ${ }^{9}$ Its effectiveness in co-morbid anxiety, social phobia and panic disorder is well known. ${ }^{11-14}$ De Paris et al again investigated the effects of $400 \mathrm{mg}$ and $800 \mathrm{mg}$ gabapentin on anxiety induced by simulated public speaking that resembles preoperative anxiety state. It showed attenuated anxiety in subjects with decrease in Visual Analogue Mood Scale and Profile of Mood State scores $^{15}$. Premedication with $900 \mathrm{mg}$ gabapentin and $300 \mathrm{mg}$ pregabalin decreases preoperative anxiety and improves sedation without producing significant side effects in patients undergoing elective abdominal hysterectomy under general anaesthesia. ${ }^{16}$ But, Clarke $\mathrm{H}$ et al. ${ }^{17}$ did not show any beneficial effect with $600 \mathrm{mg}$ gabapentin premedication in patients undergoing total hip arthroplasty but in his another study done with $1200 \mathrm{mg}$ dose, preoperative anxiety and pain scores were reduced and sedation was increased prior to entering the operating room suggesting that $1200 \mathrm{mg}$ gabapentin may be a treatment option for patients who exhibit high levels of preoperative anxiety. ${ }^{18}$ Use of single $1200 \mathrm{mg}$ dose of gabapentin premedication was very effective not only in reducing postoperative pain but also in reducing preoperative anxiety without causing amnesia, sedation and other side effects in patients undergoing various surgical procedures. ${ }^{4,519-27}$ This present study also showed that $1200 \mathrm{mg}$ gabapentin premedication significantly reduced preoperative anxiety scores 1 hour after the drug intake and just before induction of anesthesia. Recent study have also found that oral Gabapentin premedication reduced intraoperative anxiety, sedation and intraocular pressure with improved postoperative recovery in elderly patients undergoing elective intraocular surgery. ${ }^{28}$

Studies on safety issues were performed in chronic pain patients on long term Gabapentin therapy and have demonstrated adverse effects like dizziness, somnolence, confusion, headache, nausea, ataxia and weight gain. ${ }^{29,30}$ In our study, we used only a single $1200 \mathrm{mg}$ dose and observed no significant side effects. Our findings are consistent with the findings in many single dose studies related to postoperative pain where no significant side effects were observed. Neither a single patient experienced serious side effects nor any patient received treatment for it in either group throughout the study period. Postoperatively, sedation was present for half an hour after PACU admission and was mild. All patients were awake and alert at 45 minutes of PACU admission and thereafter.

The result of our study demonstrated that preemptive use of single $1200 \mathrm{mg}$ dose gabapentin significantly decreased preoperative anxiety in patients undergoing elective open cholecystectomy with very negligible side effects.

\section{CONCLUSION}

Our findings suggest that Gabapentin should be considered a potentially useful premedicant drug in relieving preoperative anxiety.

\section{ACKNOWLEDGEMENT}

I would like to thank Mr. Dharanidhar Baral, Department of Biostatistics at BPKIHS, Dharan, Nepal for helping me in statistical analysis. I would also like to thank Dr. Shiv Kumar Singh, Consultant Anaesthesia at Royal Liverpool University Hospitals, UK and Dr. Sugam Kale, Senior Consultant Anaesthesia, Alexandra Hospital, Singapore for teaching me statistics and clearing my doubts via email. I also thank my residents and operation room staffs for helping me throughout the study.

\section{REFERENCES}

1. Tiippana EM, Hamunen K, Kontinen, and Kalso E. Do surgical patients benefit from perioperative gabapentin/ pregabalin? A systematic review of efficacy and safety. Anesthesia and analgesia 2007;104(6): 1545 http://dx.doi.org/10.1213/01.ane.0000261517.27532.80 PMid:17513656

2. Caumo W, Levandovski R, Hidalgo MP. Preoperative anxiolytic effect of melatonin and clonidine on posto VKperative pain and morphine consumption in patients undergoing abdominal hysterectomy: a double-blind, randomized placebo-controlled study. JPain. 2009 Jan;10(1):100-8. http://dx.doi.org/10.1016/j.jpain.2008.08.007 PMid:19010741 
3. Kong VKF and Irwin MG. Gabapentin: a multimodal perioperative drug? British Journal of Anaesthesia.2007;99 (6):77586 http://dx.doi.org/10.1093/bja/aem316 PMid: 18006529

4. Alprarslan Turan, Beyhan Karamanhoglu, Dilek Memis, Pinar Usar, Zafer Pamukcu, Mevlut Ture. The analgesic effects of gabapentin after total abdominal hysterectomy. Anesth Analg 2004; 98:1370-3

http://dx.doi.org/10.1213/01.ANE.0000108964.70485.B2 PMid:15105217

5. Rorarius $M G$, Mennander S, Suominen P, Rintala S, Puura A, Pirhonen $R$, et al. Gabapentin for the prevention of postoperative pain after vaginal hysterectomy. Pain 2004; 110(1-2):17581. http://dx.doi.org/10.1016/j.pain.2004.03.023 PMid:15275765

6. Pandey CK, Singhal V, Kumar M, Lakra A, Ranjan R, Raza M, Singh $U$, Singh PK. Gabapentin provides effective postoperative analgesia whether administered pre-emptively or post-incision: Can J Anaesth. 2005; 52(8):827-31. http://dx.doi.org/10. 100 7/BF03021777 PMid:16189334

7. Field MJ, Holloman EF, McCleary S, Hughes J, Singh L: Evaluation of gabapentin and S-(+)-3-isobutylgaba in a rat model of postoperative pain. J Pharmacol Exp Ther 1997; 282:12426. PMid:9316831

8. Welty DF, Schielke GP, Vartanian MG, Taylor CP. Gabapentin anticonvulsant action in rats: disequilibri-um with peak drug concentrations in plasma and brain microdialysate. Epilepsy Res 1993; 16:17581. http://dx.doi.org/10.1016/0920-1211 (93)90078- L

9. Sethi A, Das B. P, Bajaj B. K. The anxiolytic activity of gabapentin in Mice. B P Koirala Institute of Health Sciences, Dharan-Nepal. The Journal of Applied Research 2005; 5 : 3.

10. de-Paris F, a b; Busnello, J.V. a; Vianna, M.R.M. a b; Salgueiro, J.B. $b$; Quevedo, J. a b; Izquierdo, I. b; Kapczinski, F. a. The anti convulsant compound gabapentin possesses anxiolytic but not amnesic effects in rats. Behav Pharmacol 2000; 11(2):169-73. http://dx.doi.org/10.1097/00008877-200004000-00009

11. John W. Norton and Emily Quarles. Gabapentin and anxiety. Hosp Pharm 2001; 36:843845.
12. Chouinard G, Beauclair L, Belanger MC. Gabapentin : longterm antianxiety and hypnotic effects in psychiatric patients with comorbid anxiety-related disorders. Can J Psychiatry 1998; 43:305. PMid:9561320

13. Grossman E, Nadler M, Sharabi Y, Thaler M, Shachar A, Shamiss A. Antianxiety treatment in patients with excessive Hypertension. Am Jhypertens 2005; 18:1174-7. http://dx.doi.org/10.1016/j.amjhyper.2005.03.728 PMid: 16182105

14. Pande AC, Pollack MH, Crockatt J, et al. Placebo-controlled study of gabapentin treatment of panic disorder. J Clin Psycho pharmacol 2000; 20:46771.

http://dx.doi.org/10.1097/00004714-200008000-00011

15. de-Paris F, Sant'Anna MK, Vianna MR, Ivan Izquierdo, Joao V. Busnello, Joao Quevedo et al. Effects of Gabapentin on Anxiety Induced by Simulated Public Speaking. Journal of Psychopharmacology 2003; 17(2):184-188.

http://dx.doi.org/10.1177/0269881103017002006 PMid:12870565

16. Ghai A, Gupta M, Rana N, Wadhera R. The effect of pregabalin and gabapentin on preoperative anxiety and sedation. Anaesth Pain \& Intensive Care. 2012;16(3):257-261

17. Clarke H, Kay J, Orser BA, Gollish J, Mitsakakis N, Katz J. Gabapentin does not reduce preoperative anxiety when given prior to total hip arthroplasty. Pain Med. 2010;11(6):966-71. http://dx.doi.org/10.1111/j.1526-4637.2010.00826.x PMid: 20353411

18. Clarke H2013 Canadian journ 2013

19. Ménigaux C, Adam F, Guignard B, Sessler DI, Chauvin M. Preoperative Gabapentin decreases anxiety and improves early functional recovery from knee surgery. Anaesth Analg 2005; 100(5):1394-9. http://dx.doi.org/10.1213/01.ANE. 0000152010.74739.B8 PMid:15845693 PMCid:PMC1351382

20. Kiskira O, Kolotoura A, Tsitsopoulos P; karmiri, E; Emexidis Th.; Pouliou, A. The effect of Gabapentin on preoperative anxiety in patients undergoing lumbar discectomy: A-557 European Journal of Anaesthesiology. 2006;23:145 http://dx.doi.org/10.1097/00003643-200606001-00518

21. Bakry AEAE, Marey $H$. The effect of gabapentin premedication on pain and anxiety during cataract surgery under peribulbar block. Egyptian Journal of Anaesthesia 2012; 28: 4347. 
http://dx.doi.org/10.1016/j.egja.2011.10.001

22. Adam F, Bordenave L, Sessler DI, Chauvin M. Effects of a single 1200-mg preoperative dose of gabapentin on anxiety and memory. Ann Fr Anesth Reanim 2012; 31(10): 223-7. http://dx.doi.org/10.1016/j.annfar.2012.05.006 PMid: 22770920

23. Dirks J, Fredensborg BB, Christensen D, Fomsgaard JS, Flyger $H$, Dahl JB. A randomized study of effects of single dose Gabapentin verses placebo on postoperative pain and morphine consumption after mastectomy. Anaesthesiology 2002; 97:5604. http://dx.doi.org/10.1097/00000542-200209000-00007

24. Turan A, Karamanhoglu B, Memis D, Hamamcioglu MK, Tukenmez B, Pamukcu Z, Kurt I. Analgesic effects of gabapentin after spinal surgery. Anesthesiology 2004; 100:935-8. http://dx.doi.org/10.1097/00000542-200404000-00025 PMid: 15087630

25. Hussain Al-Mujadi, Abdul Rahman A Refri, Mario Gueorguiev Katzarov, Najat Abbas Dehrab, Yatindra Kumar Batra, AbdulRahim Al-Qattan. Preemptive gabapentin reduces postoperative pain and opioid demand following thyroid surgery. CANJAnesth 2006; 53(3):268-273.

http://dx.doi.org/10.1007/BF03022214 PMid:16527792

26. Werner MU, Perkins FM, Holte K, Pedersen JL, Kehlet H. Effects of gabapentin in acute inflammatory pain in humans. Reg Anesth Pain Med 2001; 26:322-8. http://dx.doi.org/10.1053/rapm.2001.25070 http://dx.doi.org/10.1097/00115550-200107000-00008 PMid:11464350
27. Tirault M, Foucan L, Debaene B, Frasca D, Lebrun T, Bernard JC et al. Gabapentin premedication: assessment of preoperative anxiolysis and postoperative patient satisfaction. Acta Anaesth. Belg. 2010, 61, 203-209. PMid:21388079

28. Kavitha J, Parida S, Kundra P, Srinivasan R. Oral gabapentin premedication for elderly patients undergoing intraocular surgery. $\mathrm{Br} J$ Ophthalmol. 2013 Jul;97(7):900-4. http://dx.doi.org/10.1136/bjophthalmol-2012-302937 PMid: 23620421

29. Mao J, Chen LL. Gabapentin in pain management. Anesth Analg 2000; 91:680-7. http://dx.doi.org/10.1213/00000539-200009000-00034

30. McLean MJ, Morrell MJ, Willmore LJ, Privitera MD, Faught RE, Holmes GL, et al. Safety and tolerability of gabapentin as adjunctive therapy in a large, multi-center study. Epilepsia 1999; 40:965-72. http://dx.doi.org/10.1111/j.1528-1157.1999. tb00804.x PMid:10403221 